\title{
MONITORING NITROGEN AND INDICATORS OF NITROGEN LOADING TO SUPPORT MANAGEMENT ACTION IN BUZZARDS BAY
}

\author{
J. E. COSTA \\ Buzzards Bay Project, Massachusetts Coastal Zone Management, \\ 2 Spring St., Marion, MA, U.S.A. \\ B. L. HOWES \\ Woods Hole Oceanographic Institution, Woods Hole, MA, U.S.A. \\ A. E. GIBLIN \\ The Ecosystems Center, Marine Biological Laboratory, Woods Hole, MA, \\ U.S.A. \\ and

\section{VALIELA} \\ Boston University Marine Program, Marine Biological Laboratory, \\ Woods Hole, MA, U.S.A.
}

\subsection{INTRODUCTION}

The addition of nitrogen from anthropogenic sources is contributing to water quality degradation and habitat loss in near-coastal waters throughout the world, and in many areas, nitrogen loading is one of the most significant long-term threats that must be managed (Nixon and Pilson, 1983; Lee and Olsen, 1985; Rosenberg, 1985; Nixon, 1986; Nixon et al., 1986). The Buzzards Bay Project, a participant in the US Environmental Protection Agency's (US EPA) National Estuarine Program, has developed a Comprehensive Conservation and Management Plan (EPA and EOEA, 1991) to protect and restore water quality and living resources in Buzzards Bay, Massachusetts, USA (Fig. 29.1). A major focus of the project, and a significant threat to Buzzards Bay, is the addition of excessive amounts of nitrogen from human activities. Consequently, a nitrogen management strategy was developed whose long-term goals are to prevent adverse changes of coastal ecosystems or loss of beneficial water uses, as well as to restore areas already adversely affected by excessive contributions of nitrogen.

The Buzzards Bay Project has adopted a nitrogen management strategy based 


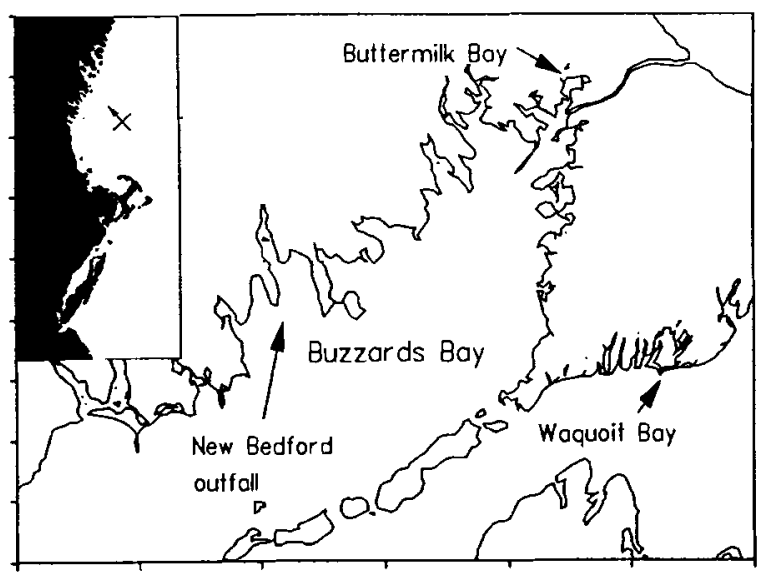

Fig. 29.1. Buzzards Bay and surrounding area (inset shows northeast U.S. seaboard). Data from Buttermilk Bay, Waquoit Bay, and the area around the New Bedford sewage treatment facility outfall are discussed in this paper.

on nitrogen loading limits, using a mass-loading approach derived from land-use analysis and data from permitted sources. This approach obviates the need for monitoring of receiving waters for either application or enforcement of this management strategy. Instead, the nitrogen monitoring program described here will be used to evaluate the effectiveness or need for management action, including the appropriateness of the nitrogen loading rate limits chosen.

It is difficult to develop a monitoring program to quantify inputs and impacts of nitrogen to coastal waters for several reasons. First, inorganic nitrogen is rapidly taken up, transformed, or removed from the water column, so that indirect effects rather than nitrogen must be monitored. Second, the response of coastal ecosystems to nitrogen loading is complex and variable, and depends on secondary factors like bathymetry and flushing. Overall, the relationship between different nitrogen loading rates and ecosystem level changes is poorly understood. Third, it is difficult to quantify with certainty existing loadings where cumulative inputs of nitrogen from nonpoint sources predominate. Finally, changes in nitrogen loading, and the response of coastal ecosystems to this loading, is incremental, often spanning decades. Thus, many years of monitoring may be required to identify new trends.

In another paper the authors discuss the technical basis and implementation process for the Buzzards Bay Project's strategy to manage nitrogen (Costa et al., 1992). To integrate effectively monitoring with this or any other management strategy requires a monitoring program that answers well-defined questions. It would be academic, however, to discuss an idealized nitrogen monitoring strategy without considering the many obstacles that must be overcome to implement such a monitoring program. These obstacles include program cost, institutional limitations, lack of consistent or appropriately applied methodologies, inadequate 
data management, coordination of separate monitoring programs, and appropriate interpretation of data (see review by NRC, 1990).

This paper outlines a proposed monitoring program for Buzzards Bay that is cost effective, and is supportive of efforts by local, state, and federal authorities to control anthropogenic nitrogen inputs to coastal embayments. While some issues raised may be particular to Buzzards Bay, most problems addressed are generic to managers and scientists trying to characterize shallow coastal embayments. In particular the paper focuses on use of biological indicators to replace or complement water chemistry monitoring. It also discusses problems with some nitrogen chemistry methodologies that have confounded other monitoring efforts, as well as how trained volunteers can help implement components of the program that would otherwise be too costly.

\subsection{NITROGEN IN COASTAL ECOSYSTEMS}

In coastal marine environments, biologically available nitrogen tends to be in short supply and is the nutrient that typically limits growth of algae (Ryther and Dunstan, 1971; Rosenberg, 1985; van Bennekom and Wetsteyn, 1990). Consequently, the addition of excessive amounts of nitrogen to coastal waters from anthropogenic sources-often referred to as "nitrogen enrichment," or "coastal eutrophication"-results in conspicuous increases in the growth and abundance of algae. This increase in algal production causes, either indirectly or directly, most of the adverse changes in coastal ecosystems attributed to nitrogen enrichment.

The response of temperate coastal ecosystems to added anthropogenic nitrogen (referred to here as "nitrogen loading") is complex and varied, and this complicates any strategy to monitor the effects of this nitrogen loading. In general, adverse effects from increased inputs of nitrogen are most pronounced in embayments with restricted flushing or where the amount of nitrogen added is large compared to the volume of the receiving waters (Lee and Olsen, 1985; Valiela and Costa, 1988). Other important features that define the response of coastal ecosystems to nitrogen loading is the bathymetry of the receiving waters, and the area of the bay bottom that is within the photic zone.

Because Buzzards Bay is well mixed and receives relatively little nitrogen overall, it does not exhibit baywide anoxia or other critical impacts as observed in Chesapeake Bay and some other large estuaries. Instead, the effects of nitrogen inputs in Buzzards Bay are localized near the sites of input. This axiom is true even around the largest single point source of Buzzards Bay, the sewage treatment facility of the City of New Bedford, which discharges 93 million liters per day of effluent in Buzzards Bay, but whose nitrogen loading impacts are mostly limited to within several kilometers of the outfall (Howes and Taylor, 1989; Turner et al., 1989; J. Turner, pers. comm., 1990). For these reasons, shallow, poorly flushed embayments that are most sensitive to inputs of nitrogen and outfall mixing zones are the focus of management action and monitoring efforts in Buzzards Bay.

Sources and transport pathways of nitrogen will influence a monitoring design. 
Shallow, well-mixed estuary

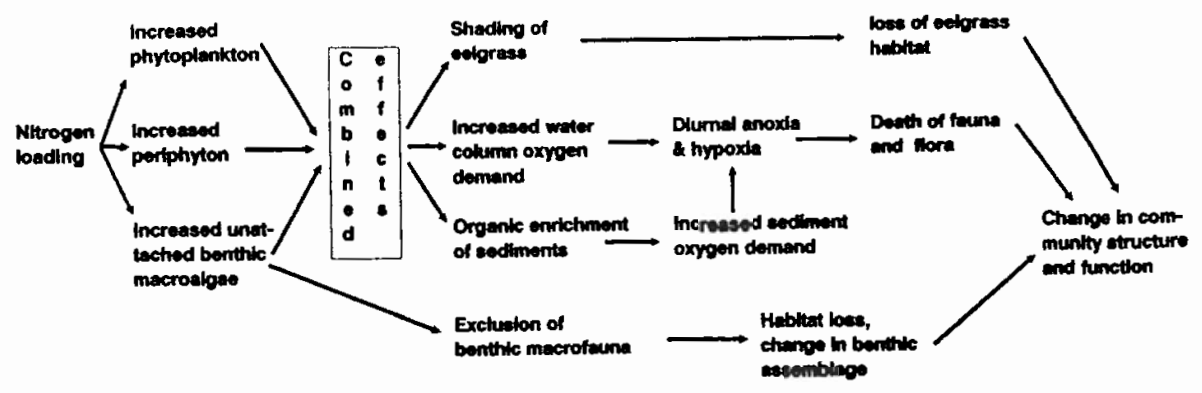

Deep, stratified estuary

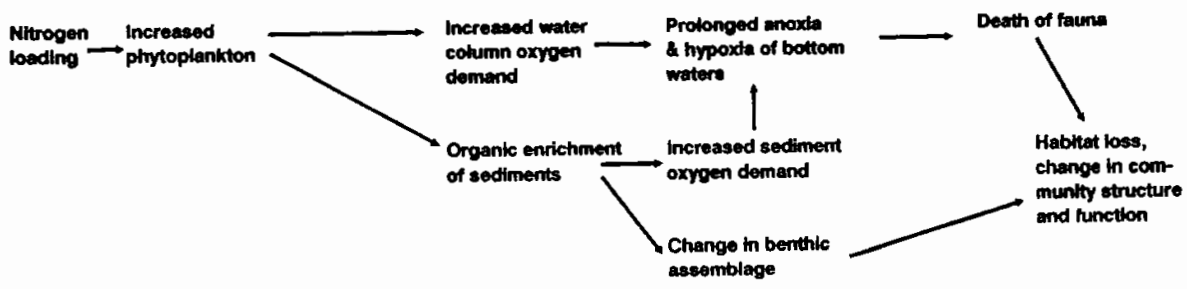

Fig. 29.2. Generalized ecosystem response of "shallow" (most of the bottom within the photic zone) and "deep" (most of the bottom below the photic zone) embayments to excessive anthropogenic nitrogen inputs. These situations represent two extremes of a continuum of hydrological and bathymetric conditions.

In Buzzards Bay as whole, sewage treatment facilities account for $44-55 \%$ of nitrogen discharged into the Bay, but in most embayments bordering Buzzards Bay, onsite septic systems and fertilizer applications on lawns and agricultural land dominate inputs (Kelly et al., 1990; SAIC, 1991). For example, in Buttermilk Bay, an embayment with landuse typical of other embayments within Buzzards Bay, septic systems account for $74 \%$ and lawn and agriculture fertilizer account for $15 \%$ of anthropogenic nitrogen contributed to the receiving waters (Valiela and Costa, 1988; Horsley Witten Hegeman, Inc., 1991).

The response of shallow, moderately well-mixed embayments, like those typical of Buzzards Bay, differs from the response of large, deep, stratified systems, and must be documented by the monitoring program. Figure 29.2 contrasts the responses of shallow and deep embayments to nitrogen loading. Reviewed below are the kinds of changes that may occur in coastal systems in response to excessive nitrogen inputs, particularly those responses typical of temperate embayments.

\subsubsection{Phytoplankton biomass and production}

When nitrogen is added to coastal waters, phytoplankton production, and often biomass (depending upon the time of year and zooplankton grazing), may increase 
substantially (Ryther and Dunstan, 1971; Jaworski, 1981; Monbet et al., 1981, Boynton et al., 1982; Cadee, 1986; D'Elia et al., 1986; Sanders et al., 1987; Magnien et al., 1988). Under enriched conditions, greater amounts of living and dead phytoplankton, zooplankton, and fecal pellets result in increased delivery and accumulation of labile organic matter to sediments (Pearson and Rosenberg, 1978; Brush and Davis, 1984; Rosenberg, 1985). As described below, increased organic matter in the water and sediment results in increased oxygen demand.

\subsubsection{Periphyton}

Where sufficient sunlight is available, periphyton-attached microalgae that grow on surfaces such as bottom sediments, rocks, and eelgrass-leaves may significantly add to local primary production (Hickman and Round, 1970). When an embayment becomes enriched, periphyton may increase appreciably in biomass under enriched conditions (Moss, 1976; Borum, 1985). Increased abundance and production of periphyton lead to increased coastal primary production, higher organic content and oxygen demand of sediments, and potentially adversely affect seagrasses due to shading resulting from colonization of the leaves (Sand-Jensen and Borum, 1983).

\subsubsection{Macroalgal abundance}

Unattached benthic macroalgae accumulate in thick layers on the bottom of some shallow bays in response to nutrient loading (Harlin and Thorne-Miller, 1981; Valiela, 1984; Lee and Olsen, 1985; Valiela and Costa, 1988; Valiela et al., 1990; Peckol, P., pers. comm., 1990). This accumulation may drastically change the abundance and species composition of fauna found in affected areas and change the nature of benthic habitats (Thorne-Miller et al., 1983).

The accumulation of benthic macroalgae exclude infauna and epifauna by preventing normal feeding behavior, water exchange, or larval recruitment. For example, shellfish habitat may disappear because dense accumulation of drift macroalgae form an impenetrable layer preventing oxygenated water from reaching the bottom, smothering bivalves and other infauna present (Lee and Olsen, 1985). In Waquoit Bay (Cape Cod, Massachusetts), the filamentous green algae, Cladophora, accumulated during the 1970 s and 1980 s now covers $70 \%$ of the bay to depths of 5 to $50 \mathrm{~cm}$ (Kelly et al., 1990; Valiela, unpubl.). Prior to the 1970s, Waquoit Bay had a large bay scallop (Argopecten irradians) population, but today the algal-covered substrate is unsuitable for the survival of scallops, which are now absent except in sandy littoral sediments near the mouth of the bay (Costa, 1988a; unpublished; Figs 29.3 and 29.4).

Dense layers of algae also lead to loss of habitat suitable for juvenile winter flounder (Lee and Olsen, 1985), other economically important finfish species, and, as described below, seagrass populations. Accumulated algae cause bay sediments to become more reduced and organically enriched, which in turn contributes to shifts in community structure. Mats of benthic algae also increase the release of porewater nutrients to the water column (Zimmermann and Montgomery, 1984). 

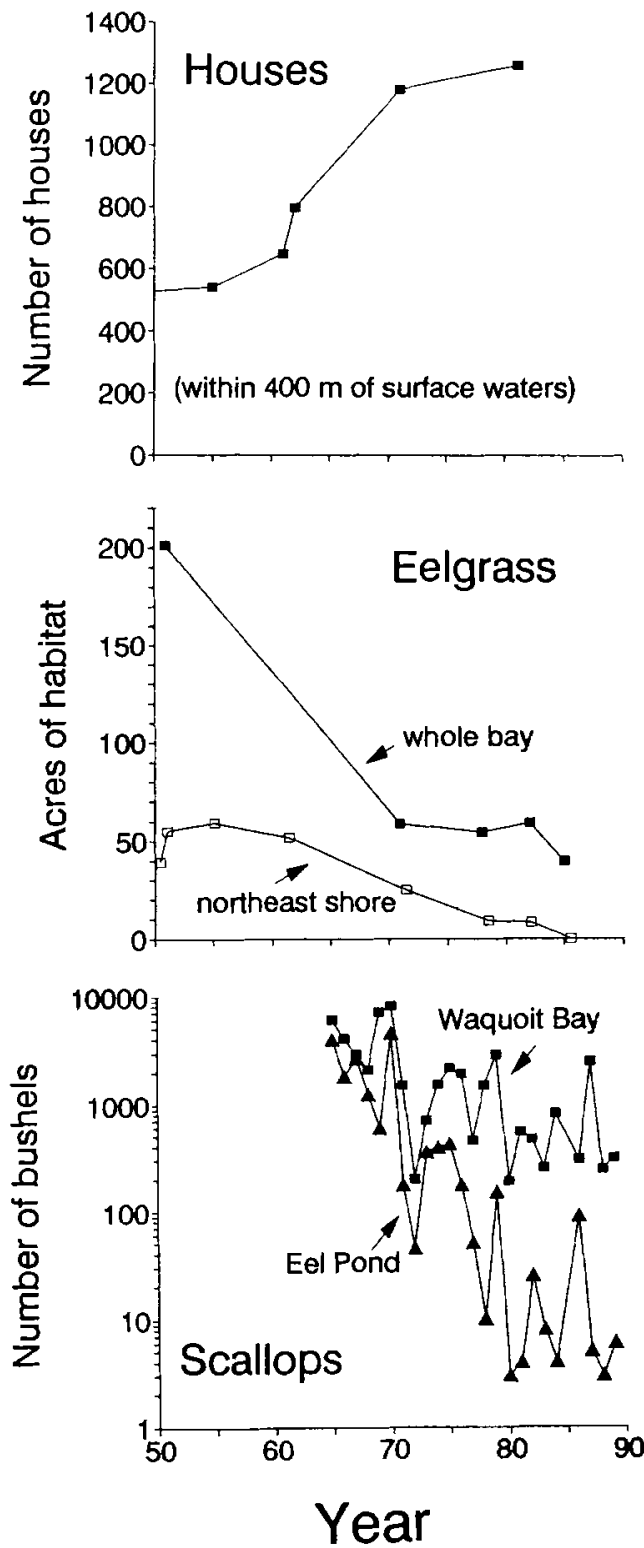

Fig. 29.3. Changes in number of houses, eelgrass abundance, and scallop catch in Waquoit Bay over time (eelgrass data from Costa (1988a, unpublished); house data from Valiela (unpublished); scallop catch statistics from Town of Falmouth annual reports). Scallop catch statistics for Waquoit Bay include catch data for two thirds of Waquoit Bay within the town of Falmouth. Scallop catch in a connecting system (Eel Pond) that experienced greater human development than Waquoit Bay, showed an even more dramatic decline in scallop catch. 
(a)

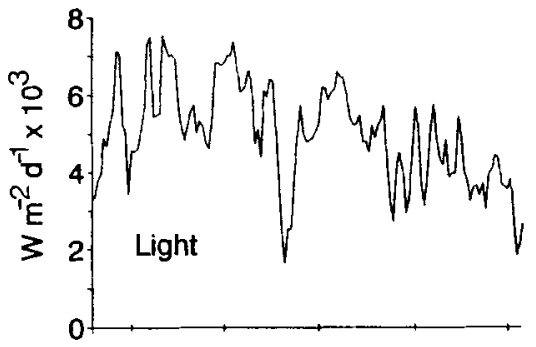

(b)

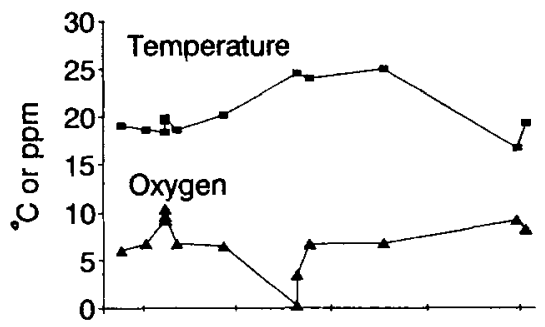

(c)

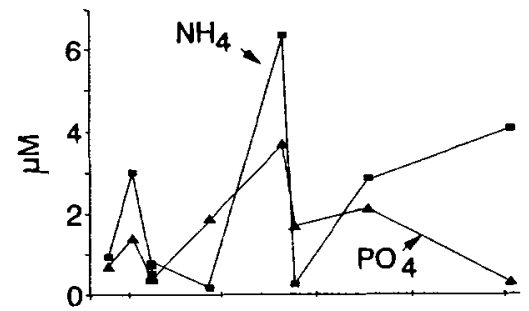

(d)

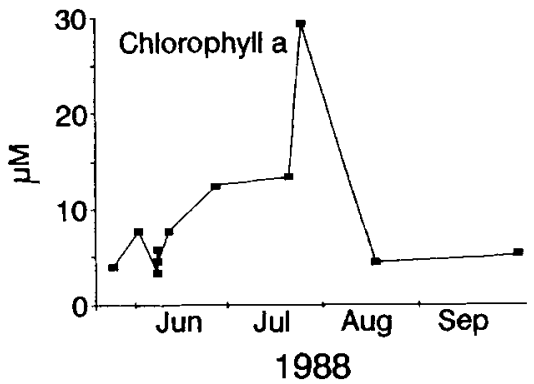

Fig. 29.4. (a) Five day running mean of daily radiant measured at the Woods Hole Oceanographic Institution from May 1 to October 1, 1988 (data from Woods Hole Oceanographic Institution, courtesy of R. Payne). During six consecutive dates (19-24 July), radiant energy was consistently below $4000 \mathrm{~W} \mathrm{~m}^{-2} \mathrm{~d}^{1}$, with two dates at $1000 \mathrm{~W} \mathrm{~m}^{-2} \mathrm{~d}^{1}$. These heavily overcast days coincided with a calm day and night on $20 \mathrm{July}$. Oxygen concentrations nearly reached $0 \mathrm{ppm}$ early morning on the $21 \mathrm{st}$ (datum courtesy of Ted Rowan), but by 1:00 PM, DO had rose to $3.6 \mathrm{ppm}$ in mid-column at this station. This anoxic event released large amounts of ammonia and phosphate (c). By 25 July, these nutrients had stimulated a high phytoplankton biomass to even higher levels (d). 
As described below, accumulation of benthic algae is an important factor contributing to anoxia in shallow embayments.

The species composition of benthic algae changes in response to loading. For example, in temperate waters, the green algae Ulva and Enteromorpha proliferate in the most eutrophic environments (Harlin et al., 1978; Kindig and Littler, 1980; Lapointe and Tenore, 1981); in moderately enriched environments, the red algae Gracilaria and Aghardiella out-compete other species and accumulate, in part because of their ability to store transient elevations of nitrogen (Deboer et al., 1978; Rosenberg and Ramus, 1982; Fujita, 1985); and in environments that receive continuous, but low nutrient inputs from sediment regeneration, species like Cladophora tend to be favored (Lapointe and O'Connel, 1989).

\subsubsection{Submerged aquatic vegetation distribution}

There is ample evidence demonstrating that the abundance of submerged angiosperms in freshwater, estuarine, and marine waters, often referred to as submerged aquatic vegetation (SAV), decline in response to large inputs of nutrients (Mulligan, 1976; Phillips et al., 1978; Cambridge, 1979; Sand-Jensen and Sendergaard, 1981; Bulthius and Woerkerling, 1983; Haramis and Carter, 1983; Nienhuis, 1983; Orth and Moore, 1983 $a$; Sand-Jensen and Borum, 1983; Twilley et al., 1985; Johansson and Lewis, in press). The primary mechanisms of decline are shading (specifically the loss of photosynthetically active radiation wavelengths) from increased phytoplankton abundance (i.e. decreased water transparency) and increased periphyton growth on SAV leaves (Phillips et al., 1978). The distribution of some attached macroalgae may also decline in response to increased nitrogen loading (Kautsky et al., 1986). The common pattern in all these environments is that the depth to which the vegetation grows decreases and vegetation disappears, first in the most enriched areas of the receiving waters and along the deeper edges of the habitat area.

In Buzzards Bay and other temperate waters, eelgrass is the most abundant angiosperm. The distribution and depth of eelgrass growth depends on the daily period of light intensity above photosynthetic saturation or compensation levels (Dennison and Alberte, 1985; Dennison, 1987). Declines in eelgrass distribution in response to nutrient loading and reduced water transparency have been widely reported (Sand-Jensen and Borum, 1983; Orth and Moore, 1983a; Costa, 1988b). In some environments, accumulations of drift algae may contribute to shading as well, and may cause death of shoots, reduction in seedling recruitment, increase in the incidence of disease, or slow vegetative growth so that losses from physical disturbances are not replaced at an adequate rate (Sand-Jensen, 1977; Kemp et al., 1983; Sand-Jensen and Borum, 1983; Borum, 1985; Costa, 1988a). Nitrogen loading in coastal waters has also been hypothesized to cause sediments to become toxic because of reduced conditions (Nienhuis, 1983) or cause increased susceptibility to disease (Short et al., 1986), but these phenomena have not been adequately documented. In general, the process of nitrogen enrichment-related eelgrass decline is gradual, often spanning decades. Boat traffic can cause significant sediment resuspension and decreased transparency (Garrad and Hey, 1987), and this may be 


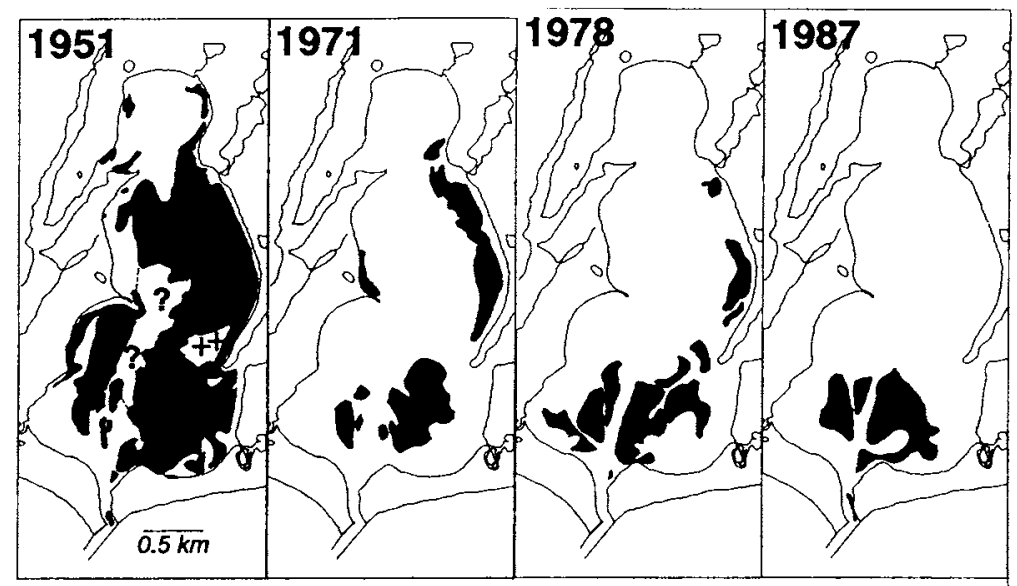

Fig. 29.5. Changes in eelgrass distribution in Waquoit Bay, MA. The depth of central portion of this bay ranges from 1.5 to $2 \mathrm{~m}$ at MLW. Changes in water quality due to increased nutrient loading resulted in the disappearance of eelgrass in the deepest and innermost portions of the Bay. Compare also to Fig. 3(f). Data from Costa (1988a, unpublished). The 1951 area indicated $(+)$ had a patchy eelgrass distribution, the area indicated (?) was a deeper portion of the bay where vegetation could not be discerned on the photograph.

an important factor contributing to eelgrass declines in some estuaries. Incidence of disease not related to nitrogen loading can be distinguished from water quality degradation-caused declines because they are rapid and both deep and shallow. Enriched and well flushed areas are equally and simultaneously affected (den Hartog, 1987).

In southern New England, eelgrass grows to a depth of $1 \mathrm{~m} \mathrm{MLW}$ or less in bays with poor water quality, but may grow as deep as $12 \mathrm{~m}$ MLW in clear offshore waters (Costa, 1988b). Declines are most dramatic when a large portion of eelgrass cover in an embayment is near the lower limit of depth distribution. For example, Apponagansett Bay and Waquoit Bay-two uniformly shallow embayments in southeastern Massachusetts (1.5-2 m)-once had extensive eelgrass populations whose maximum depth of growth coincided with the mean depth of the bays. Both embayments showed a dramatic loss in eelgrass cover in response to water quality declines (Costa, 1988b; Waquoit Bay in Fig. 29.5). In these kinds of embayments, a decrease of photic zone penetration by even $30 \mathrm{~cm}$ will result in a substantial loss of eelgrass habitat area.

Because eelgrass beds are a refuge, feeding ground, or habitat to many animals, the loss of eelgrass can result in profound shifts in fauna, including commercial and recreation species (Thayer and Stuart, 1974; Rasmussen, 1977). For example, in Waquoit Bay, decline in the catch of the bay scallop coincided with eelgrass declines (Fig. 29.3). Besides the accumulation of dense layers of macroalgae noted in section 29.2.3, the collapse of scallop populations in Waquoit Bay may have also 
occurred in part because eelgrass leaves are important settlement substrates for scallop spat in these kinds of muddy bays.

\subsubsection{Anoxic and hypoxic events}

In general, nutrient loading of coastal waters increase frequency and extent of hypoxic and anoxic conditions (Rosenberg, 1985). This phenomenon results from respiration of accumulated micro- and macroalgae, microbial decomposition, and respiration of zooplankton and macrofauna. Sediments in enriched areas show increases in organic content, finer sediment fractions, and redox potential discontinuity (RPD) layers nearer to the surface (Sanders, 1958; Pearson and Rosenberg, 1978; Brush, 1984; Brush and Davis, 1984; Nowicki and Nixon, 1985; Hampson, 1988), and sediment oxygen demand is often a large contributing factor to anoxic events. Anoxia may also cause a large release of nutrients from dying tissues or changes in sediment chemistry (Birch et al., 1983; Birch and Gabrielson, 1984).

Reduced oxygen conditions can result in diminished growth or mass mortality of many species. In larger stratified bodies of water like the Chesapeake Bay, bottom waters may remain hypoxic or anoxic for days or weeks (Officer et al., 1984, Seliger et al., 1985). During these hypoxic or anoxic periods, invertebrates and fish over large portions of the bottom of the bay die.

Mortalities caused by anoxic and hypoxic events can occur in small non-stratified coastal systems as well. In general, poorly flushed embayments that contain high benthic algal and faunal biomass (Lee and Olsen, 1985; Johansson and Lewis, in press) are most susceptible. Areas that receive disproportionately large organic loading relative to flushing and volume of the receiving waters (e.g. around sewage outfalls) may also exhibit reduced oxygen tensions.

Most embayments around Buzzards Bay are well-aerated by surface winds and well mixed. However, routine monitoring has shown that some embayments exhibit periodic hypoxic or anoxic conditions in early morning (DEP 1989a,b; see also text below), but return to oxic or supersaturated conditions by midday. In most embayments dissolved oxygen (DO) concentrations are typically lower at night and the early morning because of the absence of photosynthesis at night to meet plant and animal respiration. In enriched Buzzards Bay embayments, increased algal biomass and concentrations of organic material in the water and sediments increase oxygen demand substantially, making this natural diurnal pattern more pronounced. Critically low oxygen concentrations are most likely to occur in poorly flushed embayments when water temperatures are highest and during periods when the weather is overcast and calm, so that photosynthetic oxygen production and aeration of the water is diminished. Such an event occurred in Waquoit Bay in July 1988 (Fig. 29.4(a) and (b)). In some enriched coastal lagoons these hypoxic events may occur nightly during calm periods (Fig. 29.6).

\subsubsection{Indirect effects on macrofauna}

Mortality from hypoxic and anoxic events is an extreme manifestation of nitrogen loading, and less readily apparent changes in benthic and demersal macrofauna may precede anoxic conditions. Changes in sediment characteristics, abundance of 


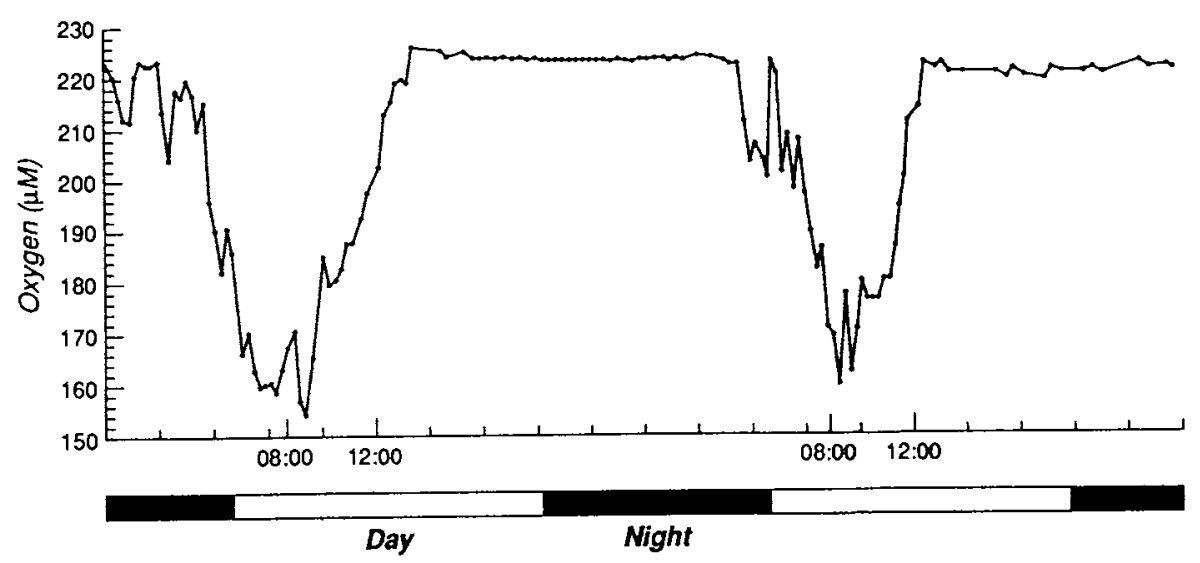

Fig. 29.6. Continuous record of oxygen concentration in Little Pond, (a coastal embayment on Cape Cod) over a two day period. Significant oxygen depletion occurred each night, yet by mid-day oxygen conditions returned to "healthy" levels due to oxygen production by algae during daylight hours. The data demonstrate the necessity for daily, early morning monitoring of oxygen in order to quantify the oxygen stress on the animals living in coastal embayments (Data from C. D. Taylor and B. L. Howes, unpublished).

plankton, organic depositional rates, can result in profound changes in the production, biomass, and species assemblage of macrofauna. These changes may result from changes in abundance of food species, loss of juvenile, adult, or egg laying habitat, and changes in the abundance or success of competitors and predators. For example, infaunal assemblages may shift from filter feeding to deposit feeding communities, show a reduction in species diversity, or show an increased abundance of small, opportunistic species (Sanders, 1958; Cederwall and Elmgren, 1980; Benkema and Cadee, 1986; Hampson, 1988). In the Dutch Wadden Sea, benthic infauna biomass doubled with a doubling or tripling of phytoplankton production (Benkema and Cadee, 1986). Concurrent with changes in biomass are changes in assemblage: near sewage outfalls or agriculture inputs, the abundance of $M y a$, a dominant and commercially important filter feeder bivalve, declined and a less economically important deposit feeding bivalve increased in abundance (Reise, 1984).

There is generally little improvement in fisheries stocks when the coastal zone is highly enriched; rather it is more likely that changes in benthic habitat and increased incidence of hypoxia result in declines in commercial fish stocks and fish diversity (Nixon et al., 1986). For example, in southern New England, increased accumulation of algae has led to the death of winter flounder (Pseudopleuronectes) eggs and loss of nursery habitat (Lee and Olsen, 1985). In general, fish assemblages change in response to habitat changes caused by nutrient loading.

\subsubsection{Other responses to nutrient loading}

Other responses to nutrient loading that have been conjectured or not adequately demonstrated or widely accepted. For example, nitrogen loading has been said to 
contribute to red tides (Rosenberg, 1985), brown tides (Cosper et al., 1987; Bettrami, 1989), and other noxious blooms of species when excess nitrogen is available, or when silica may become limiting (Smayda, New England Estuarine Research Society meeting, November 1990). Because red tides represent a human health risk to consumers of contaminated seafood and may be toxic to some filter feeders, and because brown tides contribute to mortality of filter feeders and fish (Prakash, 1967), and may contribute to loss of seagrass beds (Cosper et al., 1987), these issues require more research.

There is mounting evidence that the effects of high nutrient loading such as decreased water transparency, increased nutrients in water, and the release of dissolved organic matter from algae, all contribute to the prolonged survival and possible growth of coliform bacteria in coastal waters (Heufelder, 1988), particularly in sediments (Valiela et al., 1991). Because coliform bacteria are used to classify swimming and shellfish areas, nutrient loading may therefore indirectly contribute to the closing of these areas.

\subsection{A NITROGEN LOADING MONITORING STRATEGY FOR BUZZARDS BAY}

\subsubsection{Goals of the nitrogen monitoring strategy in Buzzards Bay}

A monitoring program to assess the effects of anthropogenic nitrogen loading must fulfill several goals: to characterize ecosystem health where unknown, to identify which embayments require management action, to determine the effectiveness of management actions taken, and to identify long-term trends in ecosystem health. In practical terms, managers must be able to answer two key questions: are nitrogen inputs to coastal receiving waters increasing or decreasing, and how are coastal ecosytems responding to these changes in nitrogen inputs.

Some environmental managers have documented changes in nitrogen loading by monitoring nitrogen concentrations in rivers and point sources, or in the receiving waters. The latter situation is only practical where dissolved inorganic nitrogen (DIN) loadings are large and show conservative mixing with seawater. For example, this approach was proposed by Lanne et al. (1990) to evaluate a strategy to reduce nitrogen inputs in the Dutch Wadden Sea and German Bight by $50 \%$ (the Rhine Action Plan). However, measuring decreases in nitrogen concentration in receiving waters is likely to be less reliable and more costly than quantifying nitrogen concentrations directly in rivers and at point discharges. A point source and river monitoring approach was adopted by environmental managers to evaluate the success of a strategy to reduce nitrogen inputs to Chesapeake Bay by $40 \%$ (Jordan et al., 1990). This kind of approach is only appropriate when if a large portion of the point and nonpoint sources reaching the receiving waters are transported via streams and rivers.

In many embayments around Buzzards Bay, and elsewhere in the region, a large component of freshwater (and nitrogen) are transported via groundwater (Valiela and Costa, 1988; Giblin and Gaines, 1990). Measuring these groundwater inputs 
is too complex and costly to do routinely, consequently it is impractical to quantify changes in nitrogen inputs in embayments by water quality monitoring alone. Instead, the effectiveness of a nitrogen management program and quantification of nitrogen inputs can best be evaluated by enumerating numbers of new septic systems, lawns, implementation of agricultural best-management practices, and other types of landuse evaluations. Only large point sources or streams conveying large fractions of the nitrogen load should be routinely monitored to quantify nitrogen inputs.

The second question, documenting the response of coastal ecosystems to changes in nitrogen loading, however, can only be answered through monitoring of water quality and living resources. While this kind of monitoring can shed light on trends of nitrogen inputs, it cannot be used to quantify those inputs. The remainder of this paper focuses on what kind of monitoring program can document the response of coastal embayments to loading.

\subsubsection{Requirements for monitoring ecosystem changes in Buzzards Bay embayments}

Monitoring to document the effects of nitrogen inputs to Buzzards Bay must be directed at coastal areas most likely to be impacted by those inputs; that is, in embayments with limited flushing or around significant point sources such as sewage outfalls. The various responses of coastal ecosystems to nutrient loading described in the first part of this paper represent the broad categories that must be considered in such a program.

Because of technical and financial limitations, it is infeasible to monitor all of the ecosystem responses described above as a part of a routine monitoring strategy. For example, it is very costly to routinely enumerate phytoplankton species composition and abundance, but it is more practical to routinely assess phytoplankton abundance by measuring chlorophyll a concentrations in seawater. Nonetheless, even routine collection and analysis of water for chlorophyll and other parameters in 30 embayments may pose considerable difficulty. An effective solution to this situation is to tier the monitoring strategy so that only a few key indicators are routinely monitored. If these indicators, or other management tools, suggest that an embayment is, or will be, adversely affected by nitrogen from development, then other components of the monitoring program can be implemented.

All ecological indicators in a nitrogen monitoring program must be practical and cost effective if they are to be widely used by managers. The application of a monitoring strategy, particularly the spatial and temporal extent of sampling, must be somewhat specific to the sources and transport pathways of nitrogen within each embayment, as well as local bathymetric, hydrological, and biotic features.

\subsubsection{Monitoring elements to quantify and characterize ecosystem response}

Described below are ten major monitoring elements and other supplementary elements that should be included in a comprehensive nitrogen monitoring strategy. In some cases, instances are described where monitoring a specific parameter has been effective in identifying trends or characterizing conditions. Table 29.1 
Table 29.1

Parameters included in monitoring strategy

\begin{tabular}{|c|c|c|c|c|}
\hline Parameter & Application & Frequency of sampling & Methods & Reference, comments \\
\hline \multicolumn{5}{|c|}{ Ecological indicators, Tier 1} \\
\hline Eelgrass distribution & $\begin{array}{l}\text { Characterization trend } \\
\text { monitoring }\end{array}$ & Every $3-5$ years & $\begin{array}{l}\text { Aerial photography } \\
\text { during June-October }\end{array}$ & $\begin{array}{l}\text { Orth and Moore (1983a); } \\
\text { Costa }(1988 b)\end{array}$ \\
\hline Dissolved oxygen & $\begin{array}{l}\text { Characterization trend } \\
\text { monitoring }\end{array}$ & $\begin{array}{l}\text { Daily, } \\
\text { July and August }\end{array}$ & $\begin{array}{l}\text { Winkler titration, } \\
\text { electrode meter }\end{array}$ & Parsons et al. (1984) \\
\hline Periphyton & $\begin{array}{l}\text { Characterization } \\
\text { Citizen monitoring tool }\end{array}$ & $\begin{array}{l}\text { Several times during } \\
\text { summer }\end{array}$ & $\begin{array}{l}\text { Growth on artificial } \\
\text { substrates attached to } \\
\text { floats }\end{array}$ & Costa $(1988 b)$ \\
\hline $\begin{array}{l}\text { Chlorophyll in water } \\
\text { column }\end{array}$ & $\begin{array}{l}\text { Characterization trend } \\
\text { monitoring }\end{array}$ & $\begin{array}{l}\text { Weekly, } \\
\text { June-September }\end{array}$ & $\begin{array}{l}\text { Trichromatic } \\
\text { spectrophotometric } \\
\text { method, fluorometric, } \\
\text { HPLC }\end{array}$ & Parsons et al. (1984) \\
\hline Secchi disk depth & $\begin{array}{l}\text { Characterization trend } \\
\text { monitoring, citizen } \\
\text { program }\end{array}$ & $\begin{array}{l}\text { Daily, } \\
\text { June-September }\end{array}$ & & \\
\hline \multicolumn{5}{|c|}{ Ecological indicators, Tier 2} \\
\hline $\begin{array}{l}\text { Benthic macroalgae } \\
\text { distribution }\end{array}$ & $\begin{array}{l}\text { Characterization, trend } \\
\text { monitoring }\end{array}$ & $\begin{array}{l}\text { Summertime, } \\
\text { every } 3-5 \text { years }\end{array}$ & $\begin{array}{l}\text { Box core and hand } \\
\text { sorting and processing }\end{array}$ & \\
\hline DIN, total nitrogen & $\begin{array}{l}\text { Characterization trend } \\
\text { monitoring }\end{array}$ & $\begin{array}{l}\text { Bimonthly, April-Sept. } \\
\text { Monthly, October- } \\
\text { March, } \\
\text { alternate years }\end{array}$ & See text & Parsons et al. (1984) \\
\hline Orthophosphate & $\begin{array}{l}\text { Characterization trend } \\
\text { monitoring }\end{array}$ & $\begin{array}{l}\text { Bimonthly, April-Sept. } \\
\text { Monthly, October- } \\
\text { March, } \\
\text { alternate years }\end{array}$ & Molybdate method & Parsons et al. (1984) \\
\hline
\end{tabular}

Clogical indicators, Tier

Benthic macroalga tribution monitoring

Characterization trend Monthly, October-

March,

Bimonthly, April-Sept. March,

alternate years 
Benthic infauna

\section{Finfish}

Extinction coefficient

\section{Special assessments \\ Sediment oxygen \\ demand}

\section{Phytoplankton production}

Sediment core analysis

Stream and groundwater inputs

Permitted point sources
Characterization trend monitoring

Characterization trend monitoring

Characterization trend monitoring

Characterization trend monitoring around outfalls

Research assessment Characterization

Historical trends of eelgrass, primary producers, fauna

Quantification of nitrogen loading rate

Compliance monitoring, Monthly quantification of nitrogen loading rate
July or August, every 3-5 years

Summertime,

every 3-5 years

Bimonthly, April-Sept.

During period of DO

minima

Bimonthly, summer, otherwise monthly; every several years

Single study

Monthly
Sediment box cores, hand Sanders (1958) sorting and identification

Seining at permanent stations

Howe and Pierce (1976); Jolly (1965)

PAR light meter

Benthic chamber or sediment core respiration

${ }^{14} \mathrm{C}$ or $\mathrm{O}_{2}$ light-dark bottle techniques

Parsons et al. (1984)

DIN, TN methodologies as above

Valiela and Costa (1988)

As required by permit and as appropriate for $\mathrm{N}$ loading assessments 
summarizes situations where it is appropriate to monitor these parameters, as well as some recommended protocols.

\subsubsection{Dissolved oxygen}

Dissolved oxygen (DO) concentrations in shallow embayments show considerable diurnal variability due to changing temperature, winds, and daily light levels (Figs 29.4 and 29.6). Consequently, DO should be measured routinely in early morning (6a.m.-10a.m.) during summer to document DO minima. Because enriched systems may be more likely to become anoxic during periods when insolation is low, water temperature is high, and winds are calm, these conditions can be used to trigger increased DO monitoring efforts. Either oxygen electrode meters or Winkler titration methodology is suitable for DO monitoring.

Because regulatory agencies are unable to deploy field personnel to monitor numerous embayments concurrently, and because it is too costly to contract out such a task or to deploy numerous continuously recording meters, only a wellcoordinated monitoring program conducted by citizens can fill this need in Buzzards Bay. Such a citizen's monitoring program, as well as the use of continuously recording DO meters in selected bays (where appropriate and feasible), is essential to document patterns of hypoxia in the embayments around Buzzards Bay and is critically important in the monitoring program.

\subsubsection{Eelgrass distribution}

The loss of submerged aquatic vegetation (SAV), such as eelgrass, is an important tool for diagnosing the health of a bay. The easiest way to monitor changes in eelgrass abundance is through periodic aerial surveys together with some field verification (Orth and Moore, 1983b). This is a highly desirable approach because other aspects of coastal ecosystems, such as erosion rates, harbor usage, salt marsh loss, and drift algae accumulation, will be documented as well. Photographs used to map eelgrass should be taken to optimize interpretation of submerged features. While it is possible to use aerial surveys taken for other purposes, such imagery may have been taken under conditions not conducive for analysis of eelgrass distribution. Aerial surveys should be conducted every 3 to 5 years depending on the importance of the coastal resource and rate of changes.

\subsubsection{Light attenuation}

Measuring the attenuation of light within an estuary can be critically important in understanding the distribution of benthic macrophytes and changes in benthic habitat, especially the measure of Photosynthetically Active Radiation (400-700 nm or PAR). For example, duration of light above the compensation point (where $\mathrm{O}_{2}$ production $=$ respiration) controls the depth distribution of eelgrass. The maximum depth in $\mathrm{m}$ of eelgrass growth is approximately equal to $1 \cdot 6 / k$, where $k$ is the light extinction coefficient (Dennison, 1987).

Light attenuation in turbid estuaries is partly due to increased phytoplankton biomass, but many factors also affect water transparency. Pierce et al. (1986) found that eight physical parameters explained most of the variation in attenuation 
coefficients in a turbid estuary, but suspended minerals, chlorophyll, and carotenoids accounted for most of the variation. In shallow embayments or estuaries with high riverine flow, suspended sediments alone may account for most light attenuation. For example, Kemp et al. (1983) found that suspended sediments were at least as important as phytoplankton and periphyton as the cause of SAV loss in the Chesapeake Bay.

Measurement of PAR downwelling extinction coefficients requires a moderately expensive field light meter, but an alternative inexpensive device, the secchi disk, has been in wide use in oceanographic studies for many decades and remains an important monitoring device today. Many studies have examined the relationship between secchi disk depth and light attenuation or chlorophyll concentrations. Secchi disk depth is sometimes used to extrapolate phytoplankton production when this information is otherwise unavailable.

Two decades of secchi disk depth data (together with SAV distribution) has been used effectively to demonstrate water transparency improvements in Tampa Bay and change in SAV resulting from improved treatment of sewage (Johansson and Lewis, in press).

Light extinction coefficients or secchi disk depth can show considerable diurnal and seasonal variability, as well as spatial variability within an embayment (see also Fig. 29.7). In general, light attenuation data are most meaningful if they are taken from fixed stations and monitored during the peak growing season for macrophytes (April-October in Buzzards Bay). For many shallow embayments, secchi disk depth cannot be measured during the times of year when water transparency is greatest (mostly fall and winter), but these data are of less value for assessing long-term trends in water transparency.

\subsubsection{Periphyton production and abundance}

In freshwater systems, the accumulation of periphyton on artificial substrates has been used to assess the degree of eutrophication (Marcus, 1980; Fairchild et al., 1985), but this technique has been rarely employed in the marine environments to characterize nitrogen loading. This is surprising since periphyton growth is probably one of the most sensitive and rapid biological indicators of nutrient loading. For example, along a nutrient gradient in a Danish estuary, biomass of eelgrass algal epiphytes increased 50-100 fold, whereas phytoplankton abundance increased only 5-10 fold over the same geographic area (Borum, 1985). Many factors, such as grazing and age of eelgrass leaves, affect the biomass of periphyton on eelgrass, but these problems can be overcome by deploying artificial substrates on floats (Costa, 1988b). After several weeks, artificial substrates, such as screening, show periphyton biomass (as measured by $\mathrm{Chl}_{2}$ ) proportional to water column DIN concentrations (Fig. 29.8). Although these techniques are experimental, they show promise as a routine water quality monitoring element to document spatial patterns of inputs and as a device to educate the citizens involved with monitoring about the impacts of nitrogen loading. A periphyton assay is useful as a relative index for identifying portions of embayments that receive the greatest volumes of 


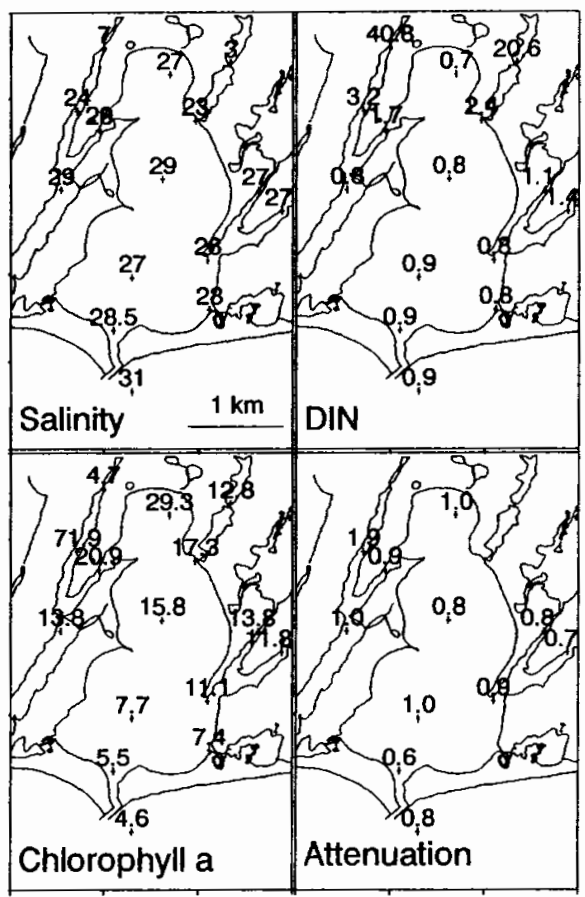

Fig. 29.7. Spatial variability of salinity (ppt), DIN $(\mu \mathrm{M}), \mathrm{Chl}_{\mathrm{a}},(\mu \mathrm{g} / \mathrm{l})$, and attenuation coefficient (Kd) in Waquoit Bay on July 27, 1989. In general, DIN, chlorophyll, and light attenuation were highest, and salinity lowest in the upper portion of the bay, and in the upper portions of the embayment subject to freshwater and groundwater inputs.

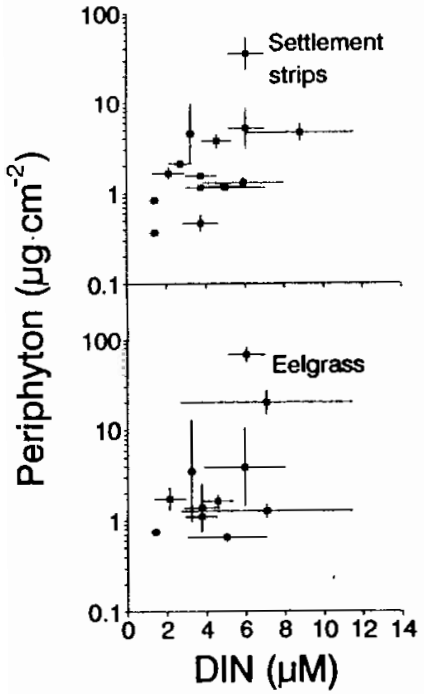

Fig. 29.8. Periphyton $\mathrm{Chl}_{\mathrm{a}}$ settlement strips (top) and eelgrass (bottom) vs. DIN during the deployment period. Standard errors of the mean are shown for three replicate strips for $\mathrm{Chl}_{a}$, and a variable number of water samples over an extended period at each station (see Costa, 1988a). 
nitrogen in relation to volume and flushing, and it is also useful for understanding the causes of eelgrass decline.

\subsubsection{Chlorophyll a}

Chlorophyll a concentrations in seawater are a useful measurement of phytoplankton response to loading. In large coastal systems and experimental mesocosms, there is often a good correlation between annual dissolved inorganic nitrogen (DIN) concentrations, nitrogen loadings, and chlorophyll a concentration (Nixon et al., 1986). In smaller, well-flushed systems, or in waters close to a nitrogen source, there may be a poor correlation between the DIN and chlorophyll because of temporal variability in both parameters; but chlorophyll concentrations tend to be higher in enriched, poorly flushed areas (Fig. 29.7). Single sample date measurements of chlorophyll are useful only as a general guide to patterns of water quality, but summer averages of chlorophyll from multiple sample dates and stations can be used to demonstrate intra-embayment variability and long-term trends. Like other water quality described here, chlorophyll data should be obtained at least weekly at fixed stations during periods of peak biological activity.

Sometimes chlorophyll a concentrations are used to estimate phytoplankton biomass or production, but generally more direct measurements should be employed to characterize these responses.

\subsubsection{Nitrogen species in seawater}

Dissolved inorganic nitrogen (DIN), i.e. nitrate, nitrite, and ammonia, are the principal forms of anthropogenic nitrogen added to coastal ecosystems, particularly where nitrogen inputs are dominated by nonpoint sources. These are also the most biologically active forms of nitrogen; hence, DIN may be transient, particularly during periods of rapid biological activity. Nixon et al. (1988) found that mean annual DIN concentrations in experimental mesocosms correlated well with nitrogen inputs. However, during some summer periods, DIN concentrations remained near the limits of detection due to uptake by phytoplankton, even in the most highly enriched experimental systems.

When DIN inputs are large in relation to the volume or flushing time of the receiving waters, DIN concentrations may reflect loadings. As described above, the discharge of nitrogen from the Rhine River far exceeds the capacity of the receiving waters to assimilate this nitrogen; consequently, DIN in the North Sea near the Danish coast is a conservative tracer of freshwater mixing and can be used to calculate loading (Lanne et al., 1990). This phenomenon is not limited to large estuaries but can also be observed on a smaller scale near creeks and streams entering coastal waters.

Rates of input and assimilation capacity are not the only factors that affect ambient DIN concentrations. Anoxic events may indirectly confound efforts to interpret enrichment conditions in coastal embayments. For example, ammonium and phosphate are typically low in Waquoit Bay, particularly on sunny days when algae are most active. During an anoxic event, however, a considerable mass of ammonia and phosphate was released into the water column (Fig. 29.4(c)) resulting 


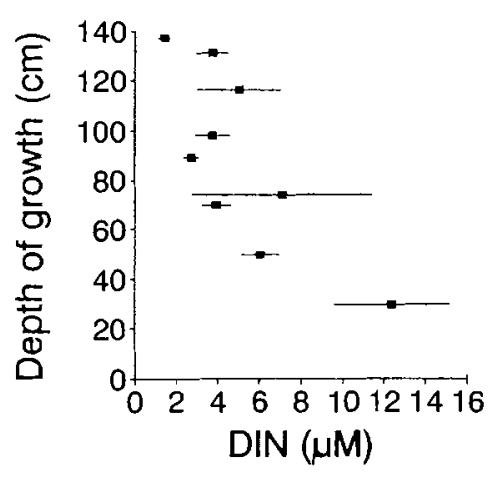

Fig. 29.9. Depth of eelgrass growth in Buttermilk Bay vs mean DIN ( \pm SE) concentration in surrounding water during the growing season (from Costa, 1988a).

in elevated concentrations of these nutrients. Chlorophyll concentrations, which were high when the anoxic event occurred (and perhaps contributed to the anoxia), doubled within several days in response this nutrient pulse (Fig. 29.4(d)), and probably contributed to the rapid, subsequent decline of ammonium.

All these phenomena suggest that care must be taken when interpreting nitrogen concentrations in seawater. In general, frequent monitoring at fixed stations is most desirable if DIN is to be used to demonstrate spatial patterns of loading or to document long-term changes in response to changes in loading. DIN concentrations in fall and winter are more likely to be indicative of relative loadings, but DIN values measured during summer are most useful when examining molar ratios of $\mathrm{N}$ and $\mathrm{P}$ to document the degree of nitrogen limitation.

While there is often a poor correlation between DIN and other water quality measurements on any particular sample date or set of sample dates, there is often a good correlation between seasonal or yearly mean DIN concentration and other parameters. For example, the maximum depth of eelgrass growth coincides with mean seasonal DIN concentrations in Buttermilk Bay (Fig. 29.9).

Although DIN is the sum of three constituents, often nitrate and nitrite are quantified together when nitrite accounts for a minor portion of DIN.

Measurement of particulate organic nitrogen (PON) in receiving waters is often considered a useful measure of the degree of loading because a large fraction of DIN that is taken up by phytoplankton remains in phytoplankton biomass. In deep estuaries dominated by riverine transport of nitrogen and phytoplankton, PON may act somewhat inversely proportional to DIN. This phenomenon would make total nitrogen an ideal loading assessment tool were it not for the fact that in shallow coastal embayments, benthic macroalgae may dominate production, scrub inorganic nitrogen from the water column, and be the primary reservoir of biologically available nitrogen. Consequently, in shallow environments, other ecological indicators such as eelgrass or benthic macroalgae are more meaningful ecological indicators than PON.

Total nitrogen (DIN + PON + dissolved organic nitrogen) is also often characterized as a useful indicator of nutrient loading. There are several ways to calculate total nitrogen in seawater, and there is considerable debate on which method is most appropriate. State and federal agencies in the past have used or 
required Total Kjeldahl Nitrogen (TKN) + Nitrate + Nitrite as the method to calculate total nitrogen because this is the method required for permitted sources. Most oceanographers and coastal biologists now consider the TKN method as inadequate and inappropriate to quantifying a moderately low concentration of total nitrogen in seawater (D'Elia et al., 1987). Instead, persulfate digestion of dissolved nitrogen fractions together with elemental analysis of particulate fractions is now the most widely accepted approach (Parsons et al., 1984; D'Elia et al., 1987). Suzuki et al. (1985) found that the persulfate digestion method may not accurately quantify dissolved inorganic nitrogen in seawater and has recommended that a high temperature combustion method be adopted. Because this technique still requires validation and is sensitive to salinity changes, and because the appropriate analytical equipment is not widely available, the persulfate digestion technique remains the preferred technique at this time. Moreover, there is also considerable disagreement over how to best calculate dissolved organic nitrogen (DON), whether it is refractory or bioavailable, and thus, whether it is meaningful to include this analysis in a monitoring program. Given the controversies surrounding measurement of total nitrogen and DON assessments, it is probably most practical to limit nitrogen monitoring to DIN and PON until these issues are resolved.

\subsubsection{Phosphorus}

Phosphorus is often monitored in marine systems, especially as dissolved inorganic phosphorus (orthophosphate) or as total phosphate. Orthophosphate is often quantified whenever DIN is quantified because the molar ratio of DIN to orthophosphate can be used to document whether nitrogen is limiting the growth of algae. That is, in environments where $\mathrm{N}: \mathrm{P}$ ratios are less than $16 \cdot 2: 1$, nitrogen is considered limiting (Ryther and Dunstan, 1971; Valiela, 1984). Care must be taken in interpreting $\mathrm{N}: \mathrm{P}$ ratios nearshore, however. For example, in Buttermilk Bay, a 200 ha embayment in Massachusetts, N:P ratios in waters at least $50 \mathrm{~m}$ from shore indicated that nitrogen was limiting during May to October (Valiela and Costa, 1988). Immediately adjacent to shore (within $10 \mathrm{~m}$ ), $\mathrm{N}: \mathrm{P}$ ratios were often considerably in excess of the Redfield ratio during the same period because nitrogen concentrations very close to shore reflect groundwater discharges that may have $\mathrm{N}$ : $\mathrm{P}$ ratios in excess of 100 rather than biological factors. Thus, the temporal and spatial scale of the nitrogen discharge and the volume of the receiving waters must be taken into consideration when evaluating $\mathrm{N}: \mathrm{P}$ ratios.

\subsubsection{Benthic macroalgae}

It is useful to quantify algal biomass and cover in coastal embayments to quantify habitat change and to estimate oxygen demand or the quantity of nitrogen tied-up in this pool. Sometimes the extent of benthic macrophyte distribution can be partially quantified using aerial photographs (e.g. Costa, 1988b), but in general, quantification must rely on intensive field sampling. There is no established method of sampling unattached, or "drift," benthic macroalgae. One typical approach is to sample an area with a sediment grab, and to sort, wash, and dry the algae for biomass or chemical composition assessments. Although labor requirements are 
intensive to sample algae, this monitoring need only be conducted every 3-6 years in bays where algae accumulate.

\subsubsection{Fish populations}

The response of fish populations to increased nitrogen loading can be documented by examining changes in species abundance, distribution, and composition over time. For example, improvements in water quality in the Thames River (England) was documented by a 7-fold increase in fish species abundance between 1960 and 1980 (Andrews and Rickard, 1980). Methods for assessing fish stocks include capture-recapture data (Seber, 1965; Jolly, 1965; Howe and Pierce, 1976) and other sampling techniques, such as collecting eggs or larvae (Yocum and Teran, 1980). In general, fish collecting efforts are very time consuming, costly, and require considerable expertise. Nonetheless, because fish assessments need only be conducted every 3-4 years, and because assessment of fish stocks is an easier concept to disseminate to the general public than complex water quality parameters, it is an important component for intermediate scale monitoring. Efforts should be made to characterize the most commercially important species, such as the winter flounder (Crawford and Carey, 1985), or indicator species and assemblages (Deegan et al., 1990).

\subsubsection{Infauna composition}

The composition and abundance of invertebrate species may change dramatically in response to enrichment. The most precise method for assessing these species is through enumerating and sorting species collected in sediment grabs or cores. Because this is a labor intensive process, and requires a high degree of expertise, this approach will only be used infrequently or for certain types of assessments such as for evaluating effects of discharges from sewage treatment facilities. To reduce costs and labor requirements, sediment grabs should be analyzed only to quantify the abundance of only certain enrichment and nonenrichment indicator species. For example, in Buzzards Bay, relevant enrichment indicator species include the bivalve Mulina and the polychaete Mediomastis (Sanders, 1960; Hampson, 1988). This type of study can be used to document the scale of impacts around a sewage treatment facility (Fig. 29.10). Enrichment indicator species may have some utility in comparative studies in embayments with different levels of nitrogen loading and this topic should be further investigated.

Delineation of commercial shellfish beds in shallow embayments and quantification of abundance not only supports nitrogen management goals but other management efforts as well. This process, however, is too costly and labor intensive to justify for routine monitoring of Buzzards Bay embayments. Instead, estimates of shellfish abundance can be inferred from shellfish catch statistics, but these data must be used with caution because of changes in harvesting effort, resource area closure status, and in the value and demand of seafood species.

\subsubsection{Special investigations and supplementary data}

Additional, more research-oriented information can be gathered to better charac- 


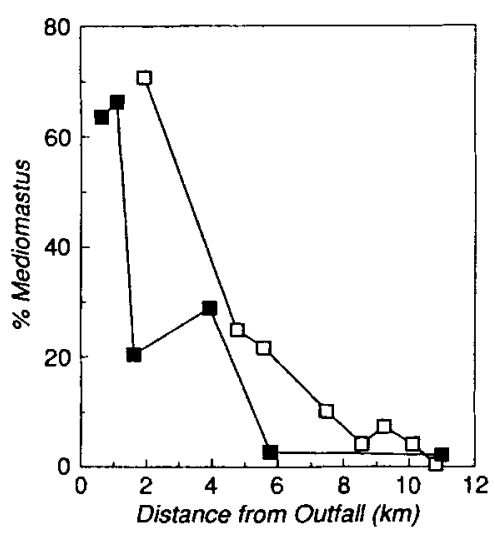

Fig. 29.10. Mediomastus (a proposed enrichment indicator species) abundance as a percent of total infauna at different distances from the New Bedford Sewage Treatment Facility outfall. Stations mostly fell along a line between the outfall and the south central portion of Buzzards Bay. Stations were at approximately equal depths and salinity. From Howes and Taylor (1989, unpublished).

terize embayments or outfall sites. These include sediment oxygen demand, stable nitrogen isotope composition, organic composition of sediments, and phytoplankton primary production.

Sediment oxygen demand can be quantified either by in situ benthic chambers or with sediment cores studied in the laboratory. Although sediment oxygen demand measurements are very useful for predicting anoxic conditions and for understanding pathways and transport of nitrogen and carbon, the time consuming and costly nature of this monitoring precludes its use as a routine monitoring tool, and this assessment can only be justifiably required in assessing plans for sewage treatment facilities or for special research studies.

Often measurement of phytoplankton primary production is needed to quantify organic loading to sediments, to estimate sediment oxygen demand, or to characterize the degree of nitrogen loading in a system. The two most widely accepted methods are the $\mathrm{O}_{2}$ and ${ }^{14} \mathrm{C}$ light-dark bottle techniques. Both techniques are widely used, but each has limitations. Because of logistical problems and cost of analysis, neither technique can be expected to be widely adopted for routine embayment monitoring in Buzzards Bay.

Whenever nitrogen species or ecological indicators of nitrogen loading are monitored in seawater, other physical and chemical measurements should be collected to permit evaluation of indicator data. These include salinity, temperature, weather conditions, tidal height, and depth of sampling. In addition, regional data on daily rainfall, surface irradiance, and wind speed and direction should be archived for evaluation. Temperature and salinity are particularly critical for evaluating dissolved oxygen concentrations because dissolved oxygen should be standardized and evaluated as percent saturation and oxygen saturation varies with temperature and salinity.

\subsubsection{Monitoring to quantify inputs}

Efforts to monitor nonpoint inputs in Buzzards Bay should be avoided because of high costs and manpower requirements, instead more effort should be directed toward monitoring ecosystem responses. If it is necessary to quantify nonpoint sources by water quality monitoring of streams, groundwater, or point sources 
then annual loadings must be calculated in a way to account for both seasonal patterns and variability of flow.

\subsubsection{Permitted sources}

Large discharges requiring regulatory permits are usually monitored for compliance with the permitted discharge limits. If no discharge limit is specified for nitrogen, it should nonetheless be quantified in sensitive areas to assist environmental planners to manage nitrogen. Analytical methods prescribed for point source monitoring may be unsatisfactory for nitrogen loading assessments. Where sewage is discharged from anaerobic systems, TKN alone may be adequate to characterize total nitrogen discharge, but where the wastestream is aerated and mixed with large volumes of stormwater, monitoring of nitrates and nitrites is very important. Because organic loading contributes to hypoxic conditions around outfalls, total organic carbon and biochemical oxygen demand should also be quantified in the effluent. Monitoring should be conducted at least weekly for the most significant nitrogen sources, such as sewage treatment facilities. These weekly measurements should be made on samples that are daily composites, preferably weighted for daily flow.

\subsubsection{Inputs from streams and groundwater}

In general, most nitrogen in streams and groundwater occurs as DIN (ammonia + nitrate + nitrite). Because DIN is also the most biologically available form of nitrogen, it is most relevant for loading estimates. Some of the larger streams discharge sizeable portions of nitrogen in organic forms, hence total nitrogen can also be used for loading calculations; but TN is not essential for tracking long-term trends in nitrogen loading.

To monitor surface water nitrogen inputs, fixed stations must be established along major streams and rivers that discharge to embayments that are the focus of management action. Stations should be established along each stream so that the contribution of components within the drainage system are understood. Stations should be positioned where stream flow can be accurately measured either from direct measure of velocity and cross-sectional area, or where stream gauges can be reliably calibrated to flow data. None of the stations should be established on portions of the river subject to seawater mixing so that attenuation or "dilution" of nitrogen species with seawater need not be factored into the loading analysis. Stations should be monitored at least every 2-3 weeks throughout the year. Deployment of continuous water samplers and continuous stream gauges will allow more precise calculation of annual nitrogen transport and these approaches should be used where appropriate.

Where streams account for most freshwater input, and where development in portions of drainage basin transporting nitrogen via groundwater and surface water is similar, stream monitoring alone can be used to document changes in annual nitrogen loading. In other situations, some groundwater stations may be considered. 


\subsubsection{Assessing historical trends}

In many instances there is considerable anecdotal information suggesting that water quality and resources have declined in response to nitrogen loading, but no historical data set exists to corroborate this trend. To help justify action to control nitrogen, historical trends in water quality and living resources can be documented using aerial photographs and sediment cores. Both these techniques can be used to document changes in eelgrass distribution. Sediment core analysis can also be used to quantify biological, physical, and chemical characteristics (e.g. stable isotope ratios, chlorophyll degradative products, diatom assemblages) that are symptomatic of enrichment and other human perturbation (Brush and Davis, 1984; Fry et al., 1987). This technique can only be used in undisturbed depositional areas away from erosion and dredging influences (Davis, 1985). This approach has proven valuable in characterizing historical trends in the Chesapeake Bay ecosystems in response to centuries of changing landuse (Brush and Davis, 1984). While sediment core analysis is not a "monitoring" element, it is an important tool for characterizing embayments.

\subsection{DISCUSSION}

The lack of a clear understanding of the relationship between specific loading rates and ecosystem response is a profound obstacle to effective management of coastal ecosystems. This is due to a relatively small data base relating nitrogen loadings in coastal embayments to changes in populations or other ecosystem changes. This lack of data is not only due to the expense of comprehensive monitoring of coastal ecosystems, but due to the interdependence among species not always being tightly coupled. For example, Orth and Moore (1983a) documented wide scale decline of submerged aquatic vegetation (SAV) in the Chesapeake Bay between 1970 and 1980. During the same period, commercial and recreational species such as herring, striped bass, and blue crabs declined, and it was conjectured that the decline of SAV and decline of fisheries were related. Seven years later, and after intensive study, this issue remains unresolved (Orth, R. J., pers. comm., 1990). Similarly, the decline of eelgrass has been cited as the cause of bay scallop (Argopectin irradians) fishery decline (Thayer et al., 1984; Eckman, 1987; Kelly et al., 1990); but because of the short life span of the bay scallop, populations are highly variable, and causal relationships are difficult to demonstrate. Other phenomena, such as the exclusion of shellifish species because of the accumulation of drift algae or death of finfish and shellfish because of hypoxic effects, are easy to demonstrate in the qualitative sense; but the scope of a fish kill or spatial extent of habitat lost are less frequently quantified and long-term ecosystem responses are not monitored.

The authors recognize that these kinds of problems must be further studied and also recognize that management decisions cannot be postponed until these issues are resolved. The monitoring program described here will help scientists and managers better document trends and help refine ongoing efforts to manage nitrogen. 


\subsubsection{Analytical methods}

It is often noted that the use of different and sometimes inappropriate methodologies, as well as the introduction of new analytical methods, have been a major obstacle in attempting to identify or interpret long-term trends in marine water quality or ecosystem health (NRC, 1990). In the marine environment this is particularly true, since practical methods for analyzing nutrients are little more than two decades old and there have been major improvements in methodologies, detection limits, accuracy, and precision. Furthermore, some of these methods are not comparable and show poor cross-correlations.

Contributing to the methodological problem are institutional barriers by regulatory agencies, which may require use of guidance compendia such as "EPA Approved Methods" or "Standard Methods for Wastewater Analysis." Many of these methods were designed for high contaminant concentrations in freshwater waste streams, and in some cases are inappropriate for measuring low level contaminant concentrations in seawater. As noted above, TKN analysis is generally the method required to quantify nitrogen discharged from permitted sources, but it is not appropriate for quantifying low level nitrogen concentrations in receiving waters (D'Elia et al., 1987), although this latter fact is often not appreciated. Consequently, considerable money and effort has been spent in some studies collecting marine water quality data of dubious validity.

This situation has arisen in part because regulatory agencies do not have the capacity to evaluate the performance of each new methodology and because the need for data comparability has slowed acceptance of new methodologies. Because compliance monitoring of receiving coastal surface waters is generally not required, and specific methodologies are not prescribed, regulatory authorities should encourage the use of marine water quality methodologies that have wide acceptance in the scientific community. That is, managers should encourage the use of methodologies that meet certain performance standards and criteria for precision, accuracy, limits of detection, and comparability.

Table 29.1 identifies methods that are most appropriate for characterizing the response of marine ecosystems to nitrogen loading. In some instances, it is desirable to use other approaches than those cited in this table. For example, if very precise determination of chlorophyll concentrations or types is desired, then an HPLC methodology should be used if the extra expense and time is warranted. Similarly, if a less accurate and precise (and less costly) determination of chlorophyll is required, such as when making multiple comparisons over many stations and depths, then fluorometric techniques should be employed. However, if both spectrophotometric and fluorometric methods are to be employed, site specific correlations between the two methods must be established.

\subsubsection{Tiering the monitoring strategy}

Dissolved oxygen, chlorophyll concentration, eelgrass distribution, and water transparency are the first tier or "sentinel" indicators that should be routinely monitored to characterize existing conditions and to document long-term trends in each embayment. These parameters were chosen because they are both cost-effective 
and sensitive to nitrogen loading. Water transparency, dissolved oxygen, and chlorophyll a should be measured annually, whereas eelgrass distribution need only be monitored every 3-5 years. Other requirements for these variables are shown in Table 29.1.

If the tier 1 indicators suggest that water quality degradation is occurring, or if the embayment is the focus of management concern, then some of the parameters in tier 2 can be monitored. These include quantifying and characterizing benthic algae, fish, shellfish, infauna, along with a detailed assessment of water chemistry. These elements are more costly, but some of the biological indicators need not be monitored annually. Use of tier 2 parameters is especially defensible in areas that have highly valued economic, ecological, or aesthetic resources.

Other monitoring parameters such as sediment oxygen demand, phytoplankton production, nitrogen load analysis and sediment core analysis of inputs, through streams and groundwater, are warranted in special studies such as evaluating the impacts of sewage treatment facilities or establishing the basis for site specific regulations to control nitrogen.

\subsubsection{Spatial and temporal requirements}

Because much of the nitrogen management effort is focused at the embayment level, most monitoring should be directed to answering embayment specific questions. There are approximately 30 embayments in Buzzards Bay ranging in size from 25 to more than $600 \mathrm{ha}$. Most are shallow, and many are dominated by macrophyte production. Water quality and resources have not been well characterized in most of these embayments.

To characterize existing water quality conditions and establish base line data for each of these embayments, DIN, orthophosphate, oxygen, light attenuation, and chlorophyll a should be monitored at fixed stations, approximately biweekly during the summer and monthly during colder months. In the smallest embayments, at least 5 stations should be established, and 20 or more in the largest embayments. Where feasible, continuously operating oxygen meters should be deployed during periods most likely subject to hypoxic conditions (i.e. July and August).

Shallow embayments may exhibit considerable spatial and temporal variability in these parameters, but seasonally averaged measurements often show distinct spatial patterns. This kind of monitoring can be conducted every few years to provide trend assessments.

\subsubsection{Implementation considerations}

State regulatory agencies have the primary responsibility for monitoring coastal waters in Massachusetts. While the scientific community may supplement this effort, research scientists cannot be expected to sustain the long-term, routine monitoring necessary to support actions to manage nitrogen. In Massachusetts and elsewhere, however, it is difficult to finance any new monitoring efforts and, wherever possible, existing monitoring programs must be modified or redirected to support this nitrogen monitoring strategy. Since the focus of management action 
is at the embayment level, monitoring must also be directed at this level of complexity. Because embayments differ both with respect to their sensitivity to nitrogen and in their commercial, recreational, and aesthetic values, monitoring can be directed first to the most valuable and sensitive embayments when monitoring resources are limited.

Because this monitoring effort requires frequent DO assessments and other logistical difficulties, a well-coordinated citizen monitoring and participation program must be integrated in the monitoring effort. Stream volume flow data is another critically important element that citizens can collect because it is not feasible to deploy stream stage recorders within every major river and stream within the Buzzards Bay drainage basin. Other important data citizens can collect may include secchi disk depth, temperature, and salinity. Citizen monitors can also collect water samples for analysis by regulatory agencies. Not only does citizen monitoring facilitate implementation of the monitoring program that this paper outlines, but it is additionally important in that it increases public awareness of environmental degradation and increases public support for environmental action.

\subsubsection{Other efforts}

This paper has not discussed monitoring efforts by federal agencies, but several in the United States are attempting to grapple with monitoring coastal ecosystems to provide managers with information that can be used to make decisions (see review in NRC, 1990). For example, in an effort to characterize and assess national and provincial trends of marine water quality, the US EPA has developed EMAP; the National Oceanic and Atmospheric Administration (NOAA) has developed the National Status and Trends program and characterized regional landuse and marine and terrestrial habitat estimates of inputs. While these efforts may be important for characterizing regional and provincial trends in water quality and living resources, or for setting national priorities for funding research and management priorities, neither program is adequate for guiding state or municipal decisions on pollution at the embayment level. This is important to recognize in Buzzards Bay and elsewhere.

\section{REFERENCES}

Andrews, M. J. and D. G. Rickard. (1980). Rehabilitation of the inner Thames estuary. Mar. Poll. Bull., 11, 327-32.

Benkema, J. J. and G. C. Cadee. (1986). Zoobenthos responses to eutrophication of the Dutch Wadden Sea. Ophelia, 26, 55-64.

Bennekom, A. J., van and F. J. Wetsteyn. (1990). The winter distribution of nutrients in the Southern Bight of the North Sea, 1961-1978 and estuaries of the Scheldt and Rhine/ Meuse. Nether. J. Sea Res., 25, 75-87.

Bettrami, E. (1989). A mathematical model of the brown tide. Estuaries, 12, 13-17.

Birch, P. B. and J. O. Gabrielson. (1984). Cladophora growth in the Peel-Harvey estuarine system following blooms of the cyanobacteria Nodularia spumizena. Bot. Mar., 27, 17-21.

Birch, P. B., J. O. Gabrielson and K. S. Hamel. (1983). Decomposition of Cladophora: I. Field studies in the Peel-Harvey estuarine system, Western Australia. Bot. Mar., 26, 105-71. 
Borum, J. (1985). Development of epiphytic communities on eelgrass (Zostera marina) along a nutrient gradient in a Danish estuary. Mar. Biol., 87, 211-18.

Boynton, W. R., W. M. Kemp and C. W. Keefe. (1982). A comparative analysis of nutrients and other factors influencing estuarine phytoplankton production. In Estuarine Comparisons, ed. V. S. Kennedy, 69-90. Academic Press, New York.

Brush, G. S. (1984). Stratigraphic evidence of eutrophication in an estuary. Water Res., 20, $531-41$.

Brush, G. S. and F. W. Davis. (1984). Strategic evidence of human disturbance in an estuary. Quatern. Res., 22, 91-108.

Bulthuis, D. A. and W. J. Woerkerling. (1983). Biomass accumulation and shading effects of epiphytes on leaves of the seagrass, Heterozostera tasmanica, in Victoria, Australia. Aquat. Bot., 16, 137-48.

Cadee, G. C. (1986). Increased phytoplankton primary production in the Marsdiep area (Dutch Wadden Sea). Neth. J. Sea Res., 20, 285-90.

Cambridge, M. L. (1979). Seagrass Studies. In Cockburn Sound Environmental Study, Department of Conservation and Environment, Australia Report no. 2.

Cederwall, H. and R. Elmgren. (1980). Biomass increase of benthic macrofauna demonstrates eutrophication of the Baltic Sea. Ophelia Suppl., 1, 287-304.

Cosper, E. M., W. C. Dennison, E. J. Carpenter, V. M. Bricel; J. G. Mitad, S. H. Kuenstner, D. A. Cotflesh and M. Dewey. (1987). Recurrent and persistent brown tide blooms perturb coastal marine ecosystems. Estuaries, 10, 284-90.

Costa, J. E. (1988a). Distribution, production, and historical changes in abundance of eelgrass (Zostera marina L.) in Southeastern MA. PhD. Thesis, Boston University.

Costa, J. E. (1988b). Eelgrass in Buzzards Bay: Distribution, Production, and Historical Changes in Abundance, U.S. Environmental Protection Agency Technical Report, EPA 503/4-88-002.

Costa, J. E., B. L. Howes, D. Aubrey, A. Giblin, M. Frimpter, D. Janik, N. MacGaffey and I. Valiela. (1992). Managing nitrogen inputs to sensitive embayments: Technical basis for a management strategy. Buzzards Bay Project Technical Report Series, Draft report.

Crawford, R. E. and C. G. Carey. (1985). Retention of winter flounder larvae within a Rhode Island salt pond. Estuaries, 8(2B), 217-27.

Davis, F. W. (1985). Historical changes in submerged macrophyte communities of upper Chesapeake Bay. Ecology, 66, 981-93.

Deboer, J. A., H. J. Guigli, T. L. Israel and C. F. D'Elia. (1978). Nutrition studies of two red algae I. Growth rate as a function of nitrogen source and concentration. J. Phycol., 14, 261-6.

Deegan, L. A., S. Saucerman and D. Basler. (1990). Changes in the Waquoit fish community over a twenty year period (abstract). New England salt pond data book, ed. A. E. Giblin, 57-58. Woods Hole Oceanographic Institution Technical Report CRC-90-2.

D'Elia, C. F., J. G. Sanders and W. R. Boynton. (1986). Nutrient enrichment studies in a coastal plain estuary: Phytoplankton growth in large-scale, continuous cultures. Canad. Fish. Aquat. Sci., 43, 397-406.

D'Elia, C. F., R. E. Magnien, C. F. Zimmerman, P. A. Vaas, N. L. Kaumeyer, C. W. Keefe, D. V. Shaw and K. V. Wood. (1987). Nitrogen and phosphorus determinations in estuarine waters: A comparison of methods used in Chesapeake Bay monitoring. Chesapeake Bay Liaison Office, UMCEES 97-19 CBL.

den Hartog, C. (1987). "Wasting disease" and other dynamic phenomena in Zostera beds. Aquat. Bot., 27, 3-14.

Dennison, W. C. (1987). Effects of light on seagrass photosynthesis, growth and depth distribution. Aquat. Bot., 27, 15-26.

Dennison, W. C. and R. S. Alberte. (1985). Role of daily light period in depth distribution of Zostera marina L. (eelgrass). Mar. Ecol. Prog. Ser., 25, 51-61.

DEP (Department of Environmental Protection Division of Water Pollution Control). 
(1989a). Water quality survey data, 1985. Buzzards Bay Project Technical Report, BBP89-14.

DEP (Department of Environmental Protection, Division of Water Pollution Control). (1989b). Water quality survey data 1986. Buzzards Bay Project Technical Report, BBP89-16.

Eckman, J. (1987). The role of hydrodynamics in recurrent growth and survival of Argopectin irradians (L.) and Anomia simplex (d'Orbigny) within eelgrass meadows. J. Exp. Mar. Biol. Ecol., 106, 165-91.

EPA and EOEA (U.S. Environmental Protection Agency and Massachusetts Executive Office of Environmental Affairs). (1989). Buzzards Bay Comprehensive Conservation and Management Plan, Volume I. Final 8/91. 254 pp.

Fairchild, G. W., R. L. Lowe and W. B. Richardson. (1985). Algal periphyton growth on nutrient-diffusing substrates: An in situ bioassay. Ecology, 66, 465-472.

Fry, B., S. A. Macko and J. C. Zieman. (1987). Review of stable isotopic investigations of food webs in seagrass meadows. In M. J. Durako, R. C. Phillips and R. R. Lewis III (eds.), Proc. symposium on subtropical-tropical seagrasses of the southeastern United States. Florida Mar. Res. Publ., 42, 189-209.

Fujita, R. (1985). The role of nitrogen supply and variability in regulating nitrogen uptake by macroalgae and in structuring a macroalgal community. PhD. Thesis, Boston University.

Garrad, P. N. and R. D. Hey. (1987). Boat traffic, sediment resuspension and turbidity in a broadland river. J. Hydrol., 95, 289-97.

Giblin, A. E. and A. G. Gaines. (1990). Nitrogen inputs to a marine embayment: the importance of groundwater. Biogeochemistry, 10, 309-28.

Hampson, G. P. (1988). Ground truth verification of a REMOTS survey of Buzzards Bay. Buzzards Bay Project Draft Report.

Haramis, G. M. and V. Carter. (1983). Distribution of submersed aquatic macrophytes in the tidal Potomac River. Aquat. Bot., 15, 65-79.

Harlin, M. M. and B. Thorne-Miller. (1981). Nutrient enrichment of seagrass beds in a Rhode Island coastal lagoon. Mar. Biol., 65, 221-9.

Harlin, M. M., B. Thorne-Miller and G. B. Thursby. (1978). Ammonium uptake by Gracilaria sp. (Rhodophyceae) and Ulva lactuca (Chlorophyceae) in closed system fish culture. Proc. Int. Seaweed Symp., 9, 285-92.

Heufelder, G. R. (1988). Bacteriological monitoring in Buttermilk Bay. United States Environmental Protection Agency Technical Report, EPA 503/4-88-01.

Hickman, M. and F. E. Round. (1970). Primary production and standing crops of eppisammic and epipelic algae. Br. Phycol. J., 5, 247-55.

Horsley Witten Hegemann, Inc. (1991). Quantification and control of nitrogen inputs to Buttermilk Bay. Volume 1. Buzzards Bay Project Technical Report, January 1991.

Howe, A. B. and D. E. Pierce. (1976). Winter flounder estuarine year class abundance, mortality, and recruitment. Trans. Amer. Fish Society, 105, 647-57.

Howes, B. L. and C. D. Taylor. (1989). Nutrient regime of New Bedford Outer Harbor: Infaunal community structure and the significance of sediment nutrient regeneration to water column nutrient loading. Final Report, New Bedford Sewage Treatment Facilities Plan. Volume IV, Appendix R.

Jaworski, N. A. (1981). Sources of nutrients and the scale of eutrophication problems in estuaries. In Estuaries and nutrients, ed. B. J. Neilson and L. E. Cronin, 83-110. Clifton, NJ, Humana Press.

Johansson, J. O. R. and R. R. Lewis. (in press). Recent improvements of water quality and biological indicators in Hillsborough Bay, a highly impacted subdivision of Tampa Bay, Florida, U.S.A. Proc. International Conference on marine coastal eutrophication, Bologna, Italy, 21-24 March, 1990.

Jolly, G. M. (1965). Explicit estimates from capture-recapture data with both death and immigration-stochastic model. Biometrika, 52, 245-47. 
Jordan, S., K. Mountford, C. Stenger, R. Batiuk, M. Olson, D. Forsel and L. Platt. (1990). Chesapeake Bay dissolved oxygen restoration goals. October 1990 Draft report, Chesapeake Bay Program, CBP/TRS 53/90.

Kautsky, N., H. Kautsky, U. Kautsky and M. Waern. (1986). Decreased depth penetration of Fucus vesiculosus (L.) since the 1940's indicates eutrophication of the Baltic Sea. Mar. Ecol. Prog. Ser., 28, 1-8.

Kelly, J. T., D. J. Hersh and I. Valiela. (1990). Nitrogen pollution in Buzzards Bay. Buzzards Bay Project Draft Report.

Kemp, W. M., W. R. Boynton, R. R. Twilley, J. C. Stevenson and J. C. Means. (1983). The decline of submerged vascular plants in Upper Chesapeake Bay: Summary of results concerning possible causes. Mar. Tech. Soc. J., 17, 78-89.

Kindig, A. C. and M. M. Littler. (1980). Growth and primary production of marine macrophytes exposed to domestic sewage effluent. Mar. Environ. Res., 3, 81-100.

Lanne, R. W. P. M., J van Der Meer, A. DeVries and A. van Der Gressen. (1990). Monitoring the progress of attempts to reduce nutrient load and input of certain compounds in the North Sea by 50\%. Environ. Manag., 14, 221-7.

Lapointe, B. E. and J. O'Connel. (1989). Nutrient-enhanced growth of Cladophora prolifera in Harrington Sound, Bermuda: Eutrophication of a confined, phosphorus-limited marine ecosystem. Estuar. Coast. Res. Shelf Sci., 28, 347-60.

Lapointe, B. E. and K. R. Tenore. (1981). Experimental outdoor studies with Ulva fasciata Delile. I. Interaction of light and nitrogen on nutrient uptake, growth, and biochemical composition. J. Exp. Mar. Biol. Ecol., 53, 135-52.

Lee, V. and S. Olsen. (1985). Eutrophication and management initiatives for the control of nutrient inputs to Rhode Island coastal lagoons. Estuaries, 8, 191-202.

Magnien, R. E., K. G. Sellner and P. A. Vaas. (1988). Nutrient control of phytoplankton production in the Chesapeake Bay mainstream and tributaries. EOS Trans. A.G.U., 69, 1097.

Marcus, M. D. (1980). Periphytic community response to chronic nutrient enrichment by a reservoir discharge. Ecology, 61, 387-99.

Monbet, Y., F. Manaud, P. Gentien, M. Pommepuy, G. P. Aallen, J. C. Salomon and J. L'Yavanc. (1981). The use of nutrients, salinity, and water circulation data as a tool for coastal planning. In Estuaries and nutrients, ed. B. J. Neilson and L. E. Cronin, 343-72. Clifton, NJ, Humana Press.

Moss, B. (1976). The effects of fertilization and fish on community structure and biomass of aquatic macrophytes and epiphytic algal populations: an ecosystem experiment. $J$. Ecol., 64, 313-47.

Mulligan, H. F., A. Baranowski and R. Johnson. (1976). Nitrogen and phosphorus fertilization of aquatic vascular plants and algae in replicate ponds. I. Initial response to fertilization. Hydrobiologia, 48, 109-16.

NRC (National Research Council). (1990). Managing troubled waters. The role of marine environmental monitoring. Washington, DC, National Academy Press.

Nienhuis, P. H. (1983). Temporal and spatial patterns of eelgrass (Zostera marina L.) in a former estuary in the Netherlands, dominated by human activities. Mar. Tech. Soc. J., 17, 69-77.

Nixon, S. W. (1986). Nutrient dynamics and the productivity of marine coastal waters. Marine environment and pollution, ed. R. Halwagy, D. Clayton and M. Behbehani, 97-115. Oxford, The Alden Press.

Nixon, S. and M. Pilson. (1983) Nitrogen in estuarine and coastal marine ecosystems. In Nitrogen in the marine environment, ed. E. J. Carpenter and D. G. Capone, 565-648. NY, Academic Press.

Nixon, S. W., C. A. Oviatt, J. Frithsen and B. Sullivan. (1986). Nutrients and the productivity of estuarine and coastal marine ecosystems. J. Limnol. Soc. South Afr., 12, 43-71.

Nowicki, B. L. and S. Nixon. (1985). Benthic nutrient remineralization in a coastal lagoon ecosystem. Estuaries, 8, 182-90. 
Officer, C. B., R. B. Biggs, J. L. Taft, L. E. Cronin, M. A. Tyler and W. R. Boynton. (1984). Chesapeake Bay anoxia: Origin, development, and significance. Science, 223, 22-7.

Orth, R. J. and K. A. Moore. (1983a). Chesapeake Bay: An unprecedented decline in submerged aquatic vegetation. Science, 222, 51-3.

Orth, R. J. and K. A. Moore. (1983b). Submerged vascular plants: Techniques for analyzing their distribution and abundance. Mar. Tech. Soc. J., 17, 38-52.

Parsons, T. R., Y. Maita and C. M. Lalli. (1984). A Manual of Chemical and Biological Methods for Seawater Analysis. Oxford, Pergamon Press.

Pearson, T. H. and R. Rosenberg. (1978). Macrobenthic succession in relation to organic enrichment and pollution of the marine environment. Oceanogr. Mar. Biol. Ann. Rev., 16, 229-311.

Phillips, G. L., D. Eminson and B. Moss. (1978). A mechanism to account for macrophyte decline in progressively eutrophicated freshwaters. Aquat. Bot., 4, 103-26.

Pierce, J. W., D. L. Correll, B. Goldberg, M. A. Faust and W. H. Klein. (1986). Response of underwater light transmittance in the Rhode River Estuary to changes in water-quality parameters. Estuaries, 9, 169-78.

Prakash, A. (1967). Growth and toxicity of a marine dinoflagellate Gonyaulax tamarensis. J. Fish. Res. Board Can., 24, 1584-606.

Rasmussen, E. (1977). The wasting disease of celgrass (Zostera marina) and its effects on environmental factors and fauna. In Seagrass ecosystems, ed. C. P. McRoy and C. Helfferich, 1-52. New York, Marcell Dekker.

Reise, K. (1984). Indirect effects of sewage on a sandy flat in the Wadden Sea. Neth. Inst. Res. Publ. Sev., 10, 159-64.

Rosenberg, R. (1985). Eutrophication-the future marine costal nuisance. Mar. Poll. Bull., 16, 227-31.

Rosenberg, G. and J. Ramus. (1982). Ecological growth strategies in the seaweeds Gracilaria folifera (Rhodophyceae) and Ulva sp. (Chlorophyceae): soluble nitrogen and carbohydrate reserve. Mar. Biol., 66, 251-9.

Ryther, J. H. and W. M. Dunstan. (1971). Nitrogen, phosphorus, and eutrophication in the coastal marine environment. Science, 171, 1008-31.

SAIC. (1991). Characterization of pollution sources in Buzzards Bay. Buzzards Bay Project Technical Series, Final Draft, May 1991.

Sanders, H. G. (1958). Benthic studies in Buzzards Bay. I. Animal sediment relationships. Limnol. Oceanogr., 5, 138-53.

Sanders, H. L. (1960). Benthic studies in Buzzards Bay III. The structure of the soft-bottom community. Limnol. Oceanogr., 5, 138-53.

Sanders, J. G., S. V. Cibik, C. F. D'Elia and W. R. Boynton. (1987). Nutrient enrichment studies in a coastal plain estuary: changes in phytoplankton species composition. $C a n . J$. Fish. Aquat. Sci., 44, 83-90.

Sand-Jensen, K. (1977). Effect of epiphytes on eelgrass photosynthesis. Aquat. Bot., 3, $55-63$.

Sand-Jensen, K. and J. Borum. (1983). Regulation of growth in eelgrass (Zostera marina L.) communities in Danish coastal waters. Mar. Tech. Soc. J., 17, 15-21.

Sand-Jensen, K. and M. Søndergaard. (1981). Phytoplankton and epiphyte development and their shading effect on submerged macrophytes in lakes of different nutrient status. Int. Rev. ges. Hydrobiol., 66, 529-52.

Seber, G. A. F. (1965). A note on the multiple-recapture census. Biometrika, 52, 249-59.

Selinger, H. H., J. A. Boggs and W. H. Biggley. (1985). Catastrophic anoxia in the Chesapeake Bay in 1984. Science, 228, 70-3.

Short, F. T., A. C. Mathieson and J. I. Nelson. (1986). Recurrence of the eelgrass wasting disease at the border of New Hampshire and Maine, U.S.A. Mar. Ecol. Prog. Ser., 29, 89-92.

Suzuki, Y., T. Sogimura and T. Itoh. (1985). A catalytic oxidation method for the determination of Total N dissolved in seawater. Mar. Chem., 16, 83-94. 
Thayer, G. W. and H. Stuart. (1974). The bay scallop makes its bed of seagrass. Mar. Fish. Rev., 37, 27-30.

Thayer, G. W., W. J. Kenworthy and M. S. Fonseca. (1984). The ecology of eelgrass meadows of the Atlantic Coast: A community profile. U.S. Dept. Int. FWS/OBS-84/02.

Thorne-Miller, B., M. M. Harlin, G. B. Thursby, M. M. Brady-Campbell and B. A. Dworetzky. (1983). Variations in the distribution and biomass of submerged macrophytes in five coastal lagoons in Rhode Island, U.S.A. Bot. Mar., 26, 23I-42.

Turner, J. T., D. G. Borkman, W. Lima and R. W. Pierce. (1989). A seasonal study of plankton, larval fish, and water quality in Buzzards Bay, Massachusetts. Interim Data Report. Massachusetts Division of Water Pollution Control Research and Demonstration Project 87-15. May. 248 pp.

Twilley, R. R., W. M. Kemp, K. W. Staver, J. C. Stevenson and W. R. Boynton. (1985). Nutrient enrichment of estuarine submersed vascular plant communities. 1. Algal growth and effects on production of plants and associated communities. Mar. Ecol. Prog. Ser., 23, 179-91.

Valiela, I. (1984). Marine ecological processes. New York, Springer-Verlag.

Valiela, I. and J. Costa. (1988). Eutrophication of Buttermilk Bay, a Cape Cod coastal embayment: Concentrations of nutrients and watershed nutrient budgets. Environ. Manag., 12, 539-51.

Valiela, I., J. Costa, K. Foreman, J. M. Teal, B. Howes and D. Aubrey. (1990). Transport of groundwater-borne nutrients from watersheds and their effects on coastal waters. Biogeochemistry, 10, 177-97.

Valiela, I., M. Alber and M. LaMontagne. (1991). Fecal coliform loadings and stocks in Buttermilk Bay, Massachusetts and management implications. Environ. Manag., 15, 659-74.

Yocum, W. L. and F. L. Teran. (1980). Sled for sampling benthic fish larvae. Prog. Fish Cult., 42, 118-19.

Zimmermann, C. F. and J. R. Montgomery. (1984). Effects of a decomposing drift algal mat on sediment pore water nutrient concentrations in a Florida seagrass bed. Mar. Ecol. Prog. Ser., 19, 299-302. 